
April 1936

\title{
OXIDATION OF WOOL: EFFECT OF HYDROGEN PEROXIDE ON WOOL ${ }^{1}$
}

\author{
By Arthur L. Smith and Milton Harris 2
}

\begin{abstract}
The purpose of this investigation was to provide quantitative data showing the effect of oxidizing agents on wool as a basis for studying all processes in which wool is exposed to oxidation reactions. The work reported in this paper deals only with the effect of hydrogen peroxide.

Data are presented showing the effects on wool of varying the concentration, temperature, and $\mathrm{pH}$ of the hydrogen peroxide solutions, and the duration of treatment. The main point of attack during oxidation is the disulfide group of the cystine in the wool. The extent to which the wool is oxidized bears a functional relationship to the decrease in the cystine content and to the increase in the alkali-solubility of the wool.
\end{abstract}

\section{CONTENTS}

I. Introduction

II. Materials and methods. 302

III. Results and discussion

1. Effect of varying the concentration of hydrogen peroxide

2 . Effect of varying the temperature of the hydrogen peroxide solution

3. Effect of varying the duration of treatment with hydrogen peroxide... 305

$\begin{array}{rr}\text { 4. Effect of varying the } \mathrm{pH} \text { of the hydrogen peroxide solution.- } & 306 \\ \text { IV. Conclusions } & 307\end{array}$

307

\section{INTRODUCTION}

In practical wool processing, such as bleaching, carbonizing, lustering, printing, chlorination and bromination for producing "unshrinkable" finishes, and in natural aging involving the action of light, air, and moisture, wool may become partially oxidized, the extent of oxidation depending on the severity of the conditions. The quantitative estimation of the oxidation is of great importance, since previous work $[1]^{3}$ has shown that this oxidation increases the susceptibility of wool to deterioration by alkali treatments.

\footnotetext{
1 This is the first paper of a series on studies relating to the oxidation of wool.

2 Research associates at the National Bureau of Standards, representing the American Association of Textile Chemists and Colorists.

3 The numbers in brackets here and elsewhere in the text refer to the numbered references at the end of this paper.
} 
While there are several groups in proteins which may be attacked by oxidizing agents and alkalies, the evidence obtained from studies of the effects of these reagents on cystine $[2,3,4,5,6,7]$ indicates that the greatest effect is produced on the disulfide groups. However, Fruton and Clark [8] showed that the introduction of acyl groups into the amino groups of cystine greatly increases the oxidizability and its lability towards alkali. It is to be expected, therefore, that the reactivity of the disulfide group as it exists in the complex wool molecule will be very different from that of the disulfide group in pure cystine.

The present investigation was undertaken to obtain quantitative data showing the effects of various oxidizing agents on the disulfide groups in wool, and on the susceptibility of the oxidized wool to deterioration by subsequent alkali treatment. The work reported in this paper deals only with the effect of hydrogen peroxide.

\section{MATERIALS AND METHODS}

White worsted yarn prepared from raw wool which had been extracted with Stoddard solvent and washed with water, but which had received no chemical treatment, was used in this work. The yarn was further purified by extraction in a soxhlet apparatus with alcohol and ether for 6 hours each and then washed with water at $50^{\circ}$ C. All the samples were conditioned and tested in a room maintained at a relative humidity of 65 percent and a temperature of $23^{\circ} \mathrm{C}$, with the exception of those which became so gelatinous during alkali treatment that equilibrium was not readily obtained by conditioning. These samples were partially dried in an oven at about $50^{\circ} \mathrm{C}$ for 1 hour and then dried to constant weight at $105^{\circ} \mathrm{C}$. The weights of the oven-dried samples were corrected to correspond with the moisture content of the original conditioned samples. The conditioned, untreated wool contained 13.2 percent of moisture, 14.3 percent of nitrogen, 3.23 percent of sulfur, and 11.6 percent of cystine.

The total nitrogen was determined by the micro-Kjeldahl method [9], total sulfur by the oxygen-bomb method [10], and cystine by the Sullivan method [11].

Resiliency tests were made with a compressometer [1]. Breakingstrength tests were made by the single-strand method on a pendulumtype machine, the yarn being tested while wet.

The stock hydrogen peroxide used was a 10 -volume (3.03-percent) solution, about $0.005 N$ with respect to sulphuric acid, and contained 0.3 percent of acetanilide as a preservative.

In the experimental procedure, 4 -g samples of the wool yarn were treated with $400-\mathrm{ml}$ portions of hydrogen peroxide solution. The supernatant liquor was poured off, the wool washed in running distilled water until $10 \mathrm{ml}$ of the wash water would not decolorize 1 drop of a $0.075 \mathrm{~N}$ solution of potassium permanganate, and then conditioned. The susceptibility of the wool to deterioration by alkalies (referred to as alkali-solubility in this paper) was determined by treating about $2 \mathrm{~g}$ portions of wool with $200 \mathrm{ml}$ of $0.1 \mathrm{~N}$ solution of sodium hydroxide at $65^{\circ} \mathrm{C}$ for 1 hour. The wool was filtered on a Büchner funnel, washed with about 2 liters of distilled water, and conditioned or dried as was necessary. 


\section{RESULTS AND DISCUSSION}

\section{EFFECT OF VARYING THE CONCENTRATION OF HYDROGEN PEROXIDE}

Samples of wool yarn were treated for 3 hours at $50^{\circ} \mathrm{C}$ with hydrogen peroxide solutions varying in concentrations from 0.1 to 10.0 volume. Two-gram specimens of each oxidized sample were then given the alkali treatment previously described. The effects of the treatments on the physical and chemical properties of the wool are shown in tables 1 and 2 . The results indicate that the oxidation treatment has caused no significant changes in wet breaking strength, resiliency, or total sulfur content. Both the cystine and nitrogen contents decrease with increasing concentrations of peroxide and exhibit a fairly sharp drop between concentrations of 4 and 6 volume.

TABLE 1.-Effect on wool yarn of hydrogen peroxide solutions of various concentrations at $50^{\circ} \mathrm{C}$ for 3 hours

\begin{tabular}{|c|c|c|c|c|c|c|}
\hline \multicolumn{2}{|c|}{$\begin{array}{c}\text { Concentration of } \\
\mathrm{H}_{2} \mathrm{O}_{2}\end{array}$} & $\begin{array}{l}\text { Cystine } \\
\text { content }\end{array}$ & $\begin{array}{l}\text { Total } \\
\text { sulfur }\end{array}$ & $\begin{array}{l}\text { Nitrogen } \\
\text { content }\end{array}$ & $\begin{array}{l}\text { Wet } \\
\text { breaking } \\
\text { strength }\end{array}$ & $\begin{array}{l}\text { Compres- } \\
\text { sional } \\
\text { resilience }\end{array}$ \\
\hline $\begin{array}{c}\text { Volume } \\
0.0 \\
.1 \\
.5 \\
1.0 \\
2.0 \\
4.0 \\
6.0 \\
8.0 \\
10.0\end{array}$ & $\begin{array}{c}\text { Percent } \\
0.00 \\
.03 \\
.15 \\
.30 \\
.61 \\
1.21 \\
1.82 \\
2.43 \\
3.03\end{array}$ & $\begin{array}{c}\text { Percent } \\
11.6 \\
11.6 \\
11.6 \\
10.8 \\
10.7 \\
10.5 \\
9.6 \\
9.3 \\
8.4\end{array}$ & $\begin{array}{c}\text { Percent } \\
3.23 \\
3.30 \\
3.24 \\
3.24 \\
3.21 \\
3.21 \\
3.23 \\
3.20 \\
3.23\end{array}$ & $\begin{array}{c}\text { Percent } \\
14.23 \\
14.19 \\
14.14 \\
14.17 \\
14.18 \\
14.17 \\
13.99 \\
14.04 \\
14.05\end{array}$ & $\begin{array}{l}\mathrm{kg} \\
1.15 \\
1.07 \\
1.10 \\
1.09 \\
1.07 \\
1.13 \\
1.10 \\
1.08 \\
1.03\end{array}$ & $\begin{array}{c}\text { Percent } \\
53 \\
51 \\
53 \\
52 \\
51 \\
51 \\
53 \\
50 \\
50\end{array}$ \\
\hline
\end{tabular}

TABLE 2.-Effect of $0.1 \mathrm{~N}$ solutions of sodium hydroxide at $65^{\circ} \mathrm{C}$ for 1 hour on wool which has previously been treated with various concentrations of hydrogen peroxide at $50^{\circ} \mathrm{C}$ for 3 hours

[See table 1 for the effect of the hydrogen peroxide alone]

\begin{tabular}{|c|c|c|c|c|c|c|c|}
\hline \multicolumn{2}{|c|}{$\begin{array}{c}\text { Concentration of } \\
\qquad \mathrm{H}_{2} \mathrm{O}_{2}\end{array}$} & $\begin{array}{l}\text { Loss in } \\
\text { weight }\end{array}$ & $\begin{array}{l}\text { Cystine } \\
\text { content }\end{array}$ & $\begin{array}{l}\text { Total } \\
\text { sulfur }\end{array}$ & $\begin{array}{l}\text { Nitrogen } \\
\text { content }\end{array}$ & $\begin{array}{l}\text { Wet } \\
\text { breaking } \\
\text { strength }\end{array}$ & $\begin{array}{c}\text { Compres- } \\
\text { sional resil- } \\
\text { ience }\end{array}$ \\
\hline $\begin{array}{c}\text { Volume } \\
0.0 \\
.1 \\
.5 \\
1.0 \\
2.0 \\
4.0 \\
6.0 \\
8.0 \\
10.0\end{array}$ & $\begin{array}{c}\text { Percent } \\
0.00 \\
.03 \\
.15 \\
.30 \\
.61 \\
1.21 \\
1.82 \\
2.43 \\
3.03\end{array}$ & $\begin{array}{c}\text { Percent } \\
12.8 \\
18.3 \\
16.8 \\
17.7 \\
20.0 \\
20.9 \\
41.7 \\
46.1 \\
55.6\end{array}$ & $\begin{array}{c}\text { Percent } \\
2.2 \\
2.2 \\
2.2 \\
2.2 \\
2.0 \\
2.2 \\
1.4 \\
1.4 \\
1.3\end{array}$ & $\begin{array}{c}\text { Percent } \\
1.61 \\
1.73 \\
1.63 \\
1.63 \\
1.57 \\
1.76 \\
1.83 \\
1.91 \\
2.11\end{array}$ & $\begin{array}{c}\text { Percent } \\
14.03 \\
14.07 \\
13.97 \\
13.98 \\
13.91 \\
14.01 \\
13.83 \\
13.63 \\
13.67\end{array}$ & $\begin{array}{r}\mathrm{kg} \\
0.30 \\
.19 \\
.17 \\
.13 \\
.08 \\
.\end{array}$ & $\begin{array}{c}\text { Percent } \\
42 \\
42 \\
40 \\
37 \\
36 \\
36 \\
\end{array}$ \\
\hline
\end{tabular}

The alkali treatment greatly accentuates the differences produced by oxidation alone and shows an even more pronounced critical concentration of hydrogen peroxide between 4 and 6 volume. Whereas the oxidation alone showed no significant effect on the sulfur content, wet breaking strength, and resiliency of the wool, the subsequent alkali treatment produced a considerable decrease in all three. The samples treated with peroxide solution of concentrations greater than 4 volume became so gelatinous during alkali treatment that they dried to horny masses and the physical tests could not be made. 
The sulfur content of each of the alkali-treated samples which had been oxidized with peroxide solutions below concentrations of 4 volume is about one-half of the sulfur content of the original wool. This is in accord with previous studies on the effect of alkalies on wool [1], in which it was shown that on continued treatment with alkali, the sulfur content decreased and approached a constant value at approximately half the sulfur content of the original wool. The increase in total sulfur content of the alkali-treated samples which had been treated with peroxide concentrations greater than 2 volume may be attributed to the oxidation of a portion of the sulfur to a form which tends to resist splitting from the molecule.

The increase in the alkali solubility of wool treated with increasing concentrations of peroxide is of special interest since it offers a simple

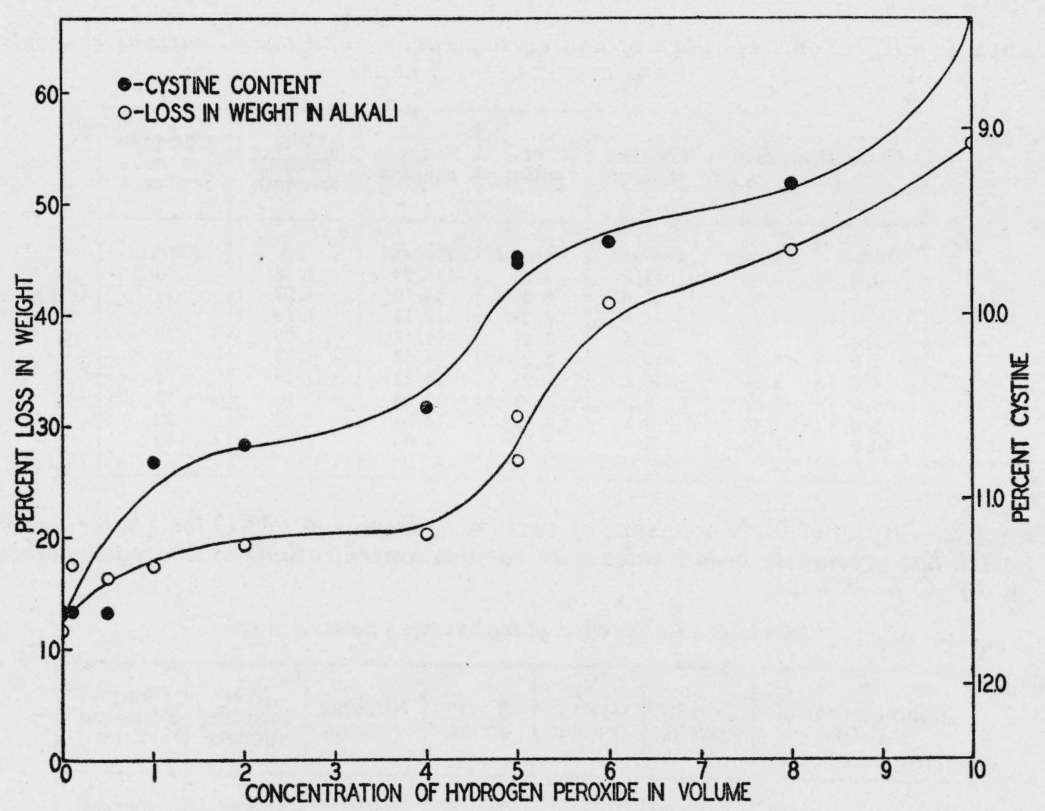

FIGURE 1.-Effect on wool of various concentrations of hydrogen peroxide for 3 hours at $50^{\circ} \mathrm{C}$.

and reproducible method for measuring the extent of oxidation. It is also of interest to note that the decrease in the cystine contents of the peroxide-treated samples bears a functional relationship to the loss in weight of the corresponding samples after alkali treatment. The curves in figure 1 show graphically the relationship of decrease in cystine content of the oxidized wool to the loss in weight when the oxidized wool is subsequently treated with alkalies.

\section{EFFECT OF VARYING THE TEMPERATURE OF THE HYDROGEN PEROXIDE SOLUTION}

Samples of wool yarn were treated with 2-volume solutions of hydrogen peroxide for 3 hours at temperatures varying from 23 to $80^{\circ}$ C. The cystine content and alkali solubility of the oxidized samples 
were determined and are given in table 3 . The cystine contents decreased and the losses in weight increased with increasing temperatures of the oxidizing bath, the rate of change increasing rapidly above $50^{\circ} \mathrm{C}$. The loss in weight in alkali appears to be the more sensitive measure of the degree of oxidation.

TABLE 3.-The effect on wool of 2-volume hydrogen peroxide solutions at temperatures varying from 23 to $80^{\circ} \mathrm{C}$ for 3 hours, and the alkali solubility of the treated wool

\begin{tabular}{|c|c|c|}
\hline $\begin{array}{c}\text { Temperature } \\
\text { of } \mathrm{H}_{2} \mathrm{O}_{2} \\
\text { solutions }\end{array}$ & $\begin{array}{c}\text { Cystine content } \\
\text { after treatment } \\
\text { with } \mathrm{H}_{2} \mathrm{O}_{2}\end{array}$ & $\begin{array}{c}\text { Alkali solu- } \\
\text { bility }\end{array}$ \\
\hline & Percent & Percent \\
\hline $\mathrm{C}$ & 11.2 & 9.7 \\
23 & 11.3 & 13.6 \\
35 & 10.8 & 19.4 \\
50 & 9.8 & 31.6 \\
65 & 7.4 & 100.0 \\
80 & & \\
\hline
\end{tabular}

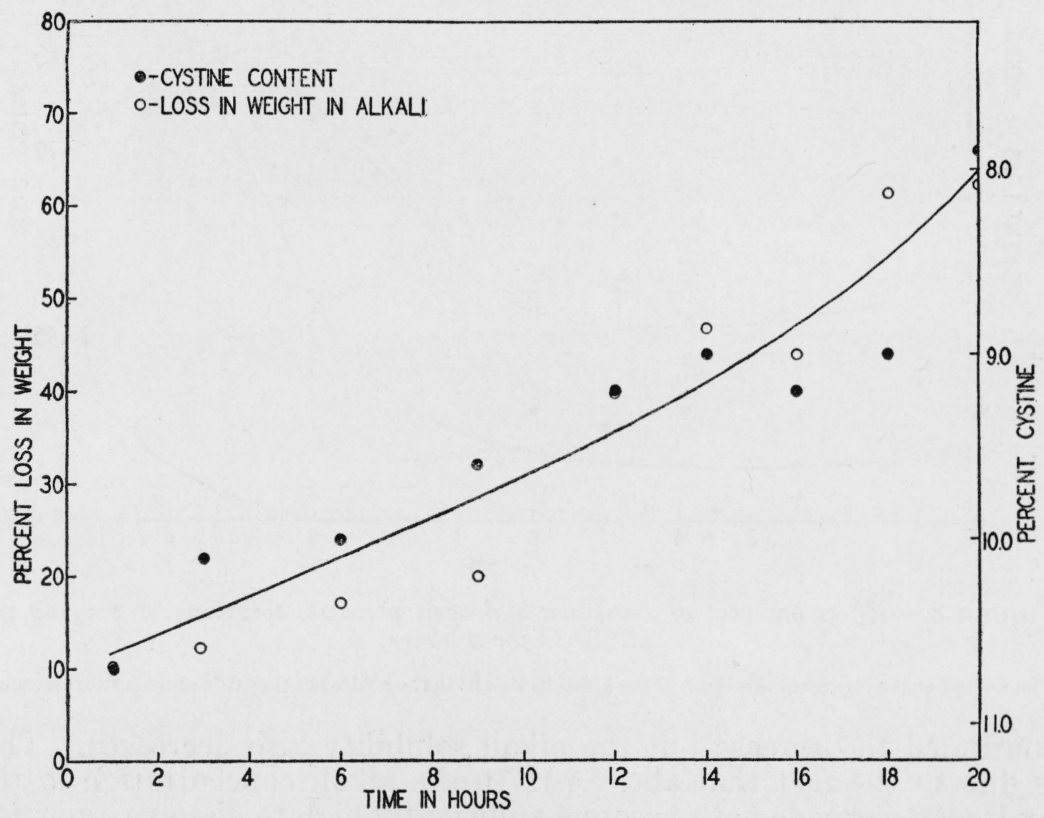

FIGURE 2.-Effect on wool of 2-volume hydrogen peroxide solutions at $50^{\circ} \mathrm{C}$ for different lengths of time.

\section{PEFECTEOF VARYING THE DURATION OF TREATMENT WITH HYDROGEN PEROXIDE}

Samples of wool yarn were treated with 2-volume solutions of hydrogen peroxide at $50^{\circ} \mathrm{C}$ for periods of time varying from 1 to 20 hours. The effects on the cystine content and alkali-solubility of the wool are shown in figure 2. While the cystine content decreases, and the loss in weight in alkali increases with increasing time of treatment, there does not appear to be any critical time under the conditions of these experiments. 


\section{EFFECT OF VARYING THE $p H$ OF THE HYDROGEN PEROXIDE SOLUTION}

Samples of wool yarn were treated with 2-volume hydrogen peroxide solutions differing in $\mathrm{pH}^{4}$ for 3 hours at $50^{\circ} \mathrm{C}$ and then analyzed for cystine content and alkali-solubility. The results, shown in figure 3 , indicate that $\mathrm{pH}$ has no appreciable effect on the oxidation of wool by peroxide below about $\mathrm{pH} 7$. Between $\mathrm{pH} 7$ and $\mathrm{pH} 10$ the alkali solubility increases and the cystine content decreases with increase in $\mathrm{pH}$. Above $\mathrm{pH} 10$ the cystine content

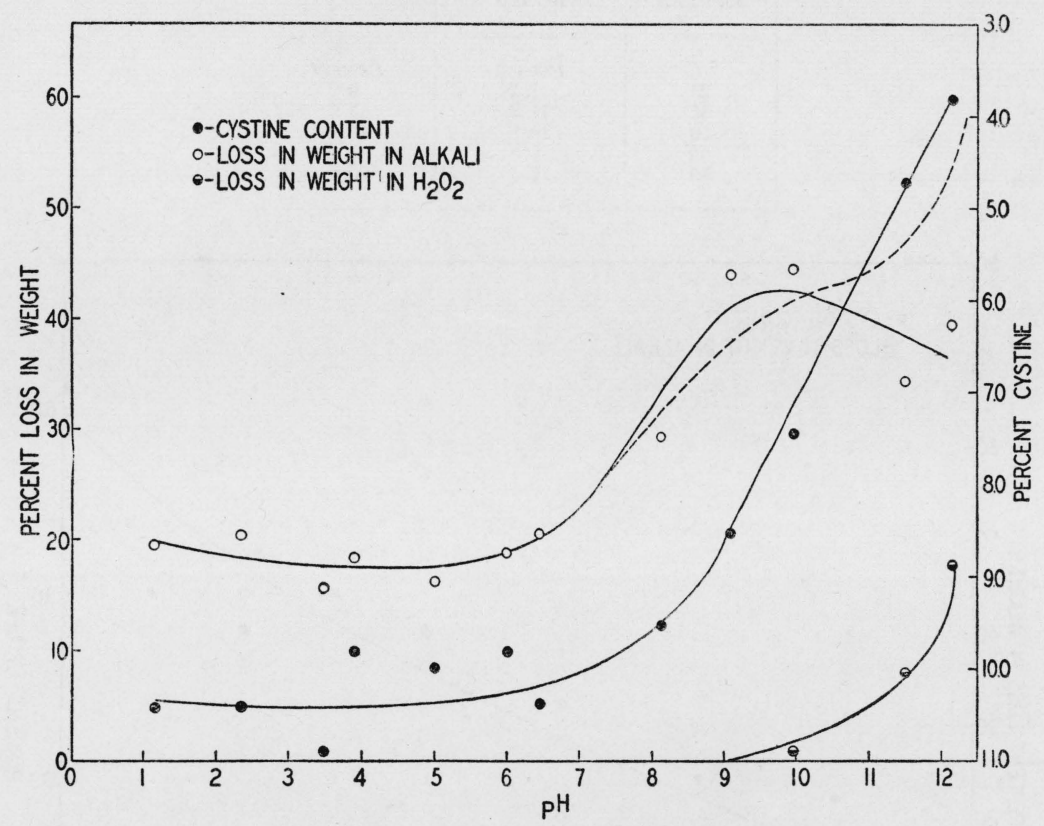

FIGURE 3.-Effect on wool of 2-volume hydrogen peroxide solutions of varying $\mathrm{pH}$ at $50^{\circ} \mathrm{C}$ for 3 hours.

The dotted curve represents the sum of the losses in weight in the hydrogen peroxide and alkali treatments.

continued to decrease but the alkali solubility also decreases. This is due to the fact that above $\mathrm{pH} 10$ the alkali concentration in the hydrogen peroxide bath becomes sufficiently high to dissolve a portion of the wool that would ordinarily be removed in the subsequent alkali treatment. When the loss in weight in the peroxide treatment is added to the loss in weight in the alkali treatment, the total loss in weight (as shown by the dotted curve in fig. 3 ) is in better agreement with the decrease in cystine content.

4 The buffers were prepared according to Clark [12] and were approximately $M / 50$ with respect to salt. 


\section{CONCLUSIONS}

Wool which has been oxidized by hydrogen peroxide solutions has a lower cystine content and a higher alkali solubility than untreated wool. The extent to which the wool is oxidized bears a functional relationship to the decrease in cystine content and to the increase in alkali solubility. In general, the latter may be considered to be the better measure of the oxidation. This is due to the fact, that although the main point of attack during oxidation is the disulfide group, there is evidence ${ }^{5}$ indicating that other groups may be attacked which may affect the alkali solubility but not the cystine content of the wool.

The extent to which wool is oxidized by hydrogen peroxide solutions depends on the concentration, temperature, and $\mathrm{pH}$ of the solutions and on the duration of treatment. The data obtained under the conditions of these experiments indicate critical values for the concentration, temperature, and $\mathrm{pH}$ of the hydrogen peroxide solutions, but not for the duration of treatment.

\section{REFERENCES}

[1] J. Research NBS 15, 63 (1935), RP810.

[2] J. Biol. Chem. 80, 191 (1928).

[3] Rev. gén. sci. 45, 593 (1934).

[4] Z. physiol. Chem. 216, 193 (1933).

[5] J. Biol. Chem. 105, 115 (1934).

[6] J. Biol. Chem. 78, 463 (1928).

[7] J. Biol. Chem. 89, 399 (1930).

[8] J. Biol. Chem. 106, 667 (1934).

[9] Pregl, Quantitative Organic Microanalysis, second edition.

[10] J. Research NBS 13, 617 (1934) RP731.

[11] Public Health Reports 86 (1930).

[12] W. M. Clark, The Determination of Hydrogen Ions, 106-7 (Williams and Wilkins Co.).

Washington, February 21, 1936.

Investigation now in progress. 